http://jmscr.igmpublication.org/home/ ISSN (e)-2347-176x ISSN (p) 2455-0450

crossref DOI: https://dx.doi.org/10.18535/jmscr/v8i5.83

\title{
Comparison of Efficacy in Diagnosis of Breast Lesions by FNAC, Frozen Section and Histopathological Study in Tertiary Care Hospital
}

\author{
Authors \\ Dr Deshpande S.A. ${ }^{1}$, Dr Makode A.J. ${ }^{2}$
}

Dr Shankarrao Chavan Medical College and Hospital, Vishnupuri, Nanded, India

\begin{abstract}
Background: In women, malignancy of breast imposes significant reduction in life span. So, FNAC is a widely accepted cytological technique in the early diagnosis of palpable breast lesions. For making further appropriate therapeutic decision intra-operative frozen section is used. Ultimately, histopathological study remains the confirmatory test in final diagnosis of breast lesions. There have been many studies of comparison of efficacy of FNAC, Frozen section and histo-pathological study which has been shown to be high in many centres.

Aim: To compare cytological and histopathological diagnosis of breast lesions and Frozen section and histopathological diagnosis of breast lesions and to establish accuracy of each of them as an diagnostic aid.

Material and Methods: FNAC of 51 cases of palpable breast lesions were evaluated retrospectively between January 2018 to June 2019. Only those cases which underwent frozen section and subsequent histopathological follow - up for confirmative diagnosis were included. FNAC, Frozen section diagnosis and Histopathological diagnoses then correlated to assess the efficacy in diagnosis of palpable breast lesions. Males and non-palpable breast lesions were excluded.

Results: The present study showed sensitivity, specificity, accuracy, positive predictive value, and negative predictive values of FNAC in relation to Histopathological diagnosis of breast lesions as $94.44 \%, 84.85 \%, 88.24 \%, 77.27 \%$, and $96.55 \%$ respectively. Also the present study showed sensitivity of $88.89 \%$, specificity of $87.89 \%$,positive predictive value of $80.00 \%$, negative predictive value of $93.55 \%$ and accuracy of $88.24 \%$ on Frozen section in relation to Histopathological study.

Conclusion: FNAC is thus a rapid, cost-effective highly sensitive and highly specific first minimal invasive method in diagnosing breast lumps. But Frozen is also sensitive and specific and has also a definite role in settings like difficult cytology, evaluation of lumpectomy margins and intra operative nodal status. But the histopathological study is still considered as a gold standard in the final diagnosis.

Keywords: FNAC; Frozen section; Histopathological study; palpable breast lesions; Malignancy of Breast.
\end{abstract}

\section{Introduction}

Breast cancer is the second most prevalent cancer among Indian women, the first being cervical cancer. The prognosis of breast cancer is primarily dependent on the extent of disease and also early diagnosis. ${ }^{(1)}$ FNAC though not entirely specific, is an important source of information in patients with breast lumps. In particular; it confidently allows exclusion of breast cancer and other more common disease and is useful in planning a 
surgical approach to the lesion ${ }^{(2)}$. It is the most common diagnostic modality for palpable breast lumps $^{(3)}$. FNAC is simple, safe and quick procedure with high sensitivity and specificity ${ }^{(4,5)}$. The accuracy rate of FNAC in diagnosing breast cancer is up to $96 \%{ }^{(6,7)}$.

The frozen section technique for intra-operative pathologic diagnosis has been used for more than 100 years. The introduction of the cryostat in 1960 established intraoperative frozen section examination as a highly reliable procedure for the rapid histological evaluation of tissue specimen during surgery ${ }^{(8)}$.

Though Fine Needle Aspiration Cytology (FNAC) has diminished the demand for frozen section evaluation of breast lumps, yet in certain situations, particularly when FNAC fails, the need for frozen section persists.

But Frozen Section it should not be used to replace paraffin embedded tissue technique. Comparatively, Frozen Section is still inferior to the later due to its various limitations. The sampling of specimen is limited and there are technical difficulties of getting good quality sections and staining of tissue and it will all influence the interpretation of the section by the pathologist.

The aim of this study was to analyze the efficacy of Fine Needle Aspiration Cytology (FNAC), frozen section and histopathological study of breast lumps. The results have been compared with published literature and the utility of these three diagnostic modalities for breast lumps has been reassessed in the present scenario.

\section{Materials and Methods}

This research included total 51 female patients of age group 11-80 years clinically presenting with palpable breast lesions referred to the Department of Pathology, for FNAC, frozen section and histopathological evaluation and a prospective study was conducted from January 2018 and June 2019.

FNAC procedure was performed according to the standard protocol $^{(9)}$. Only diagnosed cases were included in the study. Cases did not undergo surgery were excluded from the study.

The interpretation of the slides was done by the cytopathologist and treatment is decided by the surgeon from the cytological diagnosis.

All the breast specimens received in normal saline $(0.9 \%)$ solution immediately from the operation theatre without fixation in formalin were subjected for frozen section. Following this they were fixed in $10 \%$ formalin for $24 \mathrm{hrs}$ and processed for $\mathrm{H} \& \mathrm{E}$ staining for histopathological examination.

\section{Results}

In our study, all the cases in present study were female patients and no case of male patient was found.

In the present study, the age group ranged from 11-80 years. The most common age group presenting with breast lesions was 31-40 years.

The left side showed a higher frequency of breast lumps with 26 cases $(50.98 \%)$ while the right side was affected in $24(47.05 \%)$ cases and 1(1.96\%) case of Bilateral side. In the present study, 48 (94.11\%) patients presented with palpable breast lump followed by $2(3.92 \%)$ cases of palpable axillary lymph nodes and $1(1.96 \%)$ case of nipple discharge with $35(68.62 \%)$ cases presented within 6 months of duration of complaints followed by 19-24 months of duration of complaints.

Following FNAC, out of 51cases, 29(56.86\%) cases presented with malignant breast lesions and $22(43.13 \%)$ cases with benign breast lesions. In the present study, among benign lasions, $18(35.29 \%)$ cases are of fibroadenoma followed by $3(5.88 \%)$ cases of phylloides tumor and $1(1.96 \%)$ case of duct ectasia.29 (56.86\%) cases are of malignant type with Infiltrating duct carcinoma as the most common lesion.

On frozen section $31(60.78 \%)$ cases are of malignant breast lesion and 20(39.21\%) cases are of benign type. In the present study, $16(31.37 \%)$ cases are of fibroadenoma followed by $3(5.88 \%)$ cases of phylloides tumor and $1(1.96 \%)$ case of duct ectasia on frozen section study and 


\section{JMSCR Vol||08||Issue ||05||Page 461-472||May}

$31(60.78 \%)$ cases are of malignant breast lesion. Frozen section study of all the resected surgical margins of all malignant breast tumors are free of tumor tissue.

On Histopathology, 18(35.29\%) cases are of benign breast lesions and 33(64.70\%) cases are of malignant breast lesions in the present study.
Histopathogicalstudy of all resected margins of carcinoma breast are free of tumor tissue. In the present study, $14(27.45 \%)$ cases are of fibroadenoma followed by $3(5.88 \%)$ cases of phylloides tumor and 1(1.96\%) case of duct ectasia on paraffin section study and $33(64.70 \%)$ cases are malignant.

Table 1: Showing Cytohistological correlation of breast lesion diagnosis $(n=51)$

\begin{tabular}{|c|c|c|c|c|c|c|}
\hline \multirow{3}{*}{\begin{tabular}{|l|} 
Sr \\
No
\end{tabular}} & \multirow{3}{*}{\begin{tabular}{|l} 
Cytological \\
Diagnosis
\end{tabular}} & \multirow{3}{*}{$\begin{array}{l}\text { Number } \\
\text { of cases }\end{array}$} & \multicolumn{4}{|c|}{ Histopathological Diagnosis } \\
\hline & & & \multicolumn{3}{|c|}{ Benign } & \multirow{2}{*}{$\begin{array}{c}\text { Malignant } \\
\begin{array}{c}\text { Infiltrating duct } \\
\text { carcinoma }\end{array}\end{array}$} \\
\hline & & & $\begin{array}{c}\text { Fibro } \\
\text { Adenoma }\end{array}$ & $\begin{array}{c}\text { Duct } \\
\text { Ectasia }\end{array}$ & $\begin{array}{l}\text { Phylloides } \\
\text { tumor }\end{array}$ & \\
\hline A & Fibroadenoma & 18 & 14 & & & \\
\hline B & Duct ectasia & 01 & & 01 & & \\
\hline $\mathrm{C}$ & Phylloides tumor & 03 & & & 03 & \\
\hline 2 & Malignant & & & & & \\
\hline \multirow[t]{2}{*}{ A } & Infiltrating duct carcinoma & 29 & & & & 33 \\
\hline & Total & 51 & \multicolumn{3}{|c|}{18} & 33 \\
\hline
\end{tabular}

On cytohistopathology correlation, 4 cases which were benign on FNAC found to be malignant on Histopathology study.

Table 2: Showing statistical analysis of FNAC diagnosis of breast lesions in relation to paraffin section diagnosis

\begin{tabular}{|l|c|c|c|c|}
\hline \multirow{2}{*}{ FNAC } & & \multicolumn{2}{|c|}{ Histopathological Diagnosis } & Total \\
\cline { 2 - 5 } & & Benign & Malignant & \\
\hline & Benign & $17(\mathrm{a})$ & $05(\mathrm{~b})$ & 22 \\
\hline & Malignant & $01(\mathrm{c})$ & $28(\mathrm{~d})$ & 29 \\
\hline Total & & $\mathbf{1 8}$ & $\mathbf{3 3}$ & $\mathbf{5 1}$ \\
\hline
\end{tabular}

a :- True Positive ; b :- False Positive ; $c$ :- False Negative ; d :- True Negative

On statistical analysis of cytohistopathology correlation, 5 cases are False Positive on FNAC and 1 case found to be False Negative on Histopathology study. 
Table 3: Showing sensitivity, specificity, positive predictive value, negative predictive value of FNAC in relation to histopathological study of breast lesions

\begin{tabular}{|l|c|c|}
\hline Sr No. & Parameter & $\begin{array}{c}\text { VALUE } \\
(\mathbf{\%})\end{array}$ \\
\hline 1 & Sensitivity & $\mathbf{9 4 . 4 4}$ \\
\hline 2 & Specificity & $\mathbf{8 4 . 8 5}$ \\
\hline 3 & Positive predictive value & $\mathbf{7 7 . 2 7}$ \\
\hline 4 & Negative predictive value & $\mathbf{9 6 . 5 5}$ \\
\hline 5 & Accuracy & $\mathbf{8 8 . 2 4}$ \\
\hline
\end{tabular}

Table 4: Showing statistical analysis of Frozen Section diagnosis in relation to paraffin section diagnosis of breast lesions

\begin{tabular}{|l|c|c|c|c|}
\hline \multirow{2}{*}{ Frozen section } & & \multicolumn{2}{|c|}{ Histopathological Diagnosis } & Total \\
\cline { 2 - 5 } & & Benign & Malignant & \\
\hline & Benign & $16(\mathrm{a})$ & $04(\mathrm{~b})$ & 20 \\
\hline & Malignant & $02(\mathrm{c})$ & $29(\mathrm{~d})$ & 31 \\
\hline Total & & $\mathbf{1 8}$ & $\mathbf{3 3}$ & $\mathbf{5 1}$ \\
\hline
\end{tabular}

a :- True Positive ; b :- False Positive ; c :- False Negative ; :- True Negative

On statistical analysis of Frozen Section and histopathology correlation, 4 cases are False Positive on Frozen section and 2 cases are found to be False Negative on Histopathology study

Table 5: Showing sensitivity, specificity, positive predictive value, negative predictive value of Frozen Section in relation to histopathological study of breast lesions

\begin{tabular}{|l|c|c|}
\hline Sr No & Parameter & VALUES \% \\
\hline 1 & Sensitivity & $\mathbf{8 8 . 8 9}$ \\
\hline 2 & Specificity & $\mathbf{8 7 . 8 8}$ \\
\hline 3 & Positive predictive value & $\mathbf{8 0 . 0 0}$ \\
\hline 4 & Negative predictive value & $\mathbf{9 3 . 5 5}$ \\
\hline 5 & Accuracy & $\mathbf{8 8 . 2 4}$ \\
\hline
\end{tabular}

Table 6: Showing total number of cases on FNAC, Frozen Section and Histopathological diagnosis of breast lesions $(\mathrm{n}=51)$

\begin{tabular}{|l|c|c|c|c|}
\hline Sr No & Diagnosis & Benign & Malignant & Total \\
\hline 1 & FNAC & 22 & 29 & 51 \\
\hline 2 & Frozen Section & 20 & 31 & 51 \\
\hline 3 & HPE & 18 & 33 & 51 \\
\hline
\end{tabular}




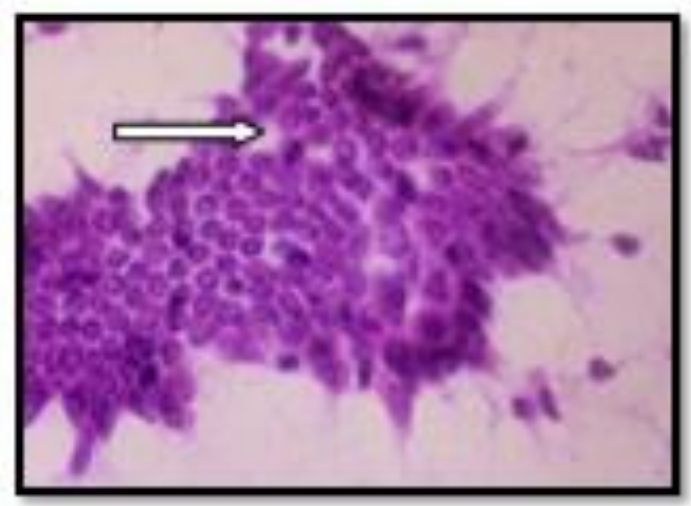

Fig No.1_- Photomicrograph of FNAC slide, Fibroadenoma of Breast ( $H$ \& E ; 40x) tightly cohesive cluster of monolayered ductal epithelial cells(white arrow) along with Bipolar cell in the [jackground.

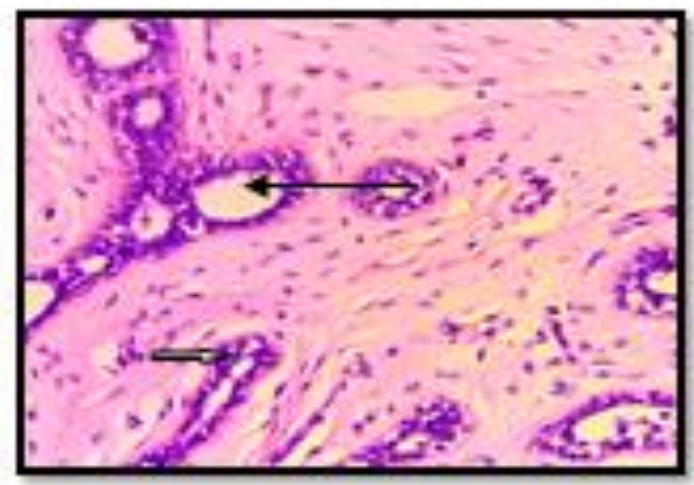

Fig No.3: Photomicrograph of Paraffin section slide, Fibroadenoma (.H\& $\mathrm{E} ; 40 \mathrm{X}$ ) show tumor comprised of intracanalicular (white arrow) and pericanalicular pattern (black arrow) of ducts having two cell types lining i.e. inner cuboidal epithelial \& outer mycepithelial. Stroma is abundant.

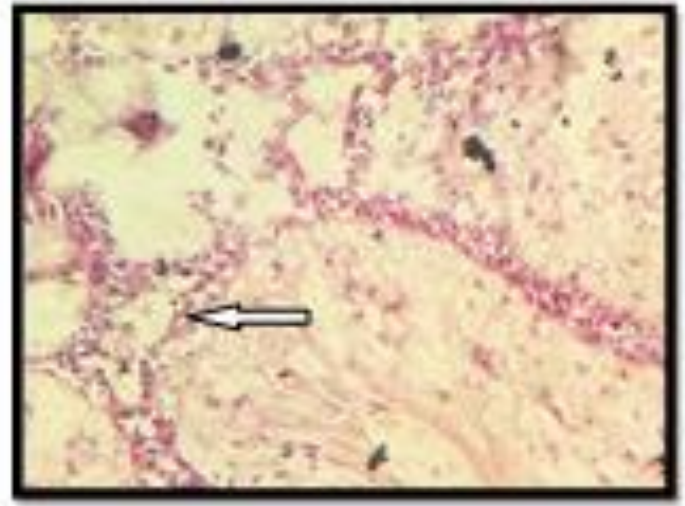

Fig. 2: Photomicrograph of Frozen section slide, Fibroadenoma ( H \& $E$; $40 \mathrm{X}$ )show tumor comprised of slit like or dilated ducts (white arrow) having two cell types lining i.e. inner cuboidal epithelial $\&$ outer myoepithelial. Stroma is abundant.

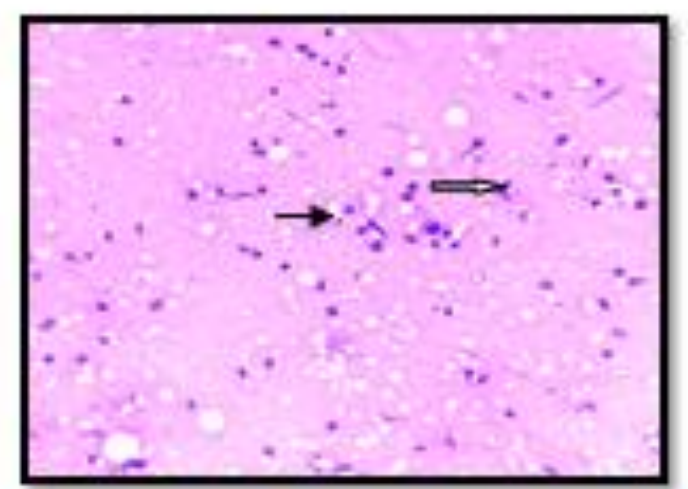

Fig No. 4: Photomicrograph of FNAC slide, Duct ectasia. (H\& E $; 40 x$ ) show areas of necrosis along with very few ductal epithelial cells(white arrow) and inflammatory infiltrate comprising of lymphocytes,cyst macrophages(black arrow). 


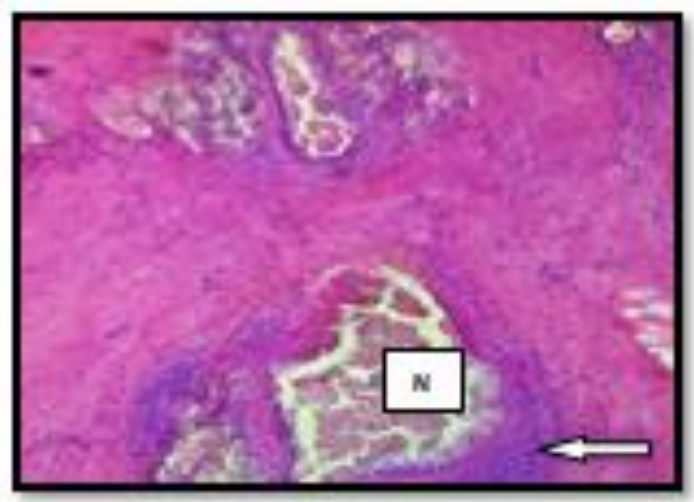

Fig No. 5 : Photomicrograph of Frozen Section slide, Duct ectasia. (H \&E , 10x) shows dilated ducts filled with necrosis(N) and inspissated secrefions surrounded by inflammatory cells (white arrow) and ductal epithelial cells.

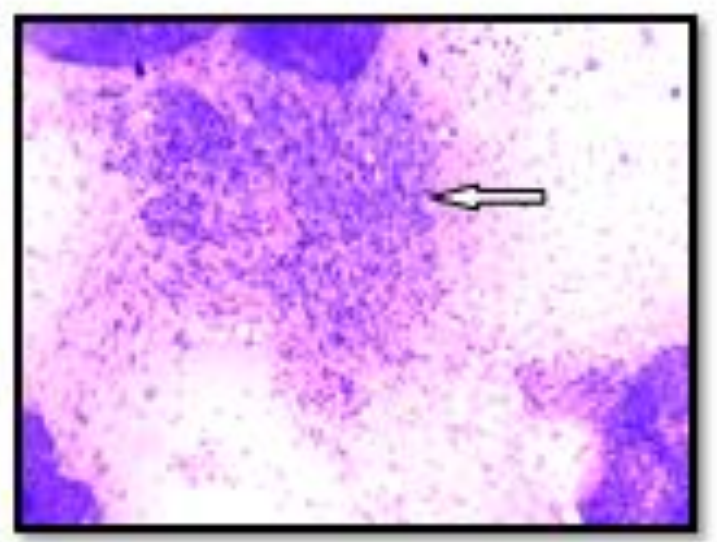

Fig. 7: Photomicrograph of FNAC slide, phylloides tumor (H \&E. i10x)shows hypercellular smear showing hypercellularity(white arrow) scattered ductal epithelial cells in the background.

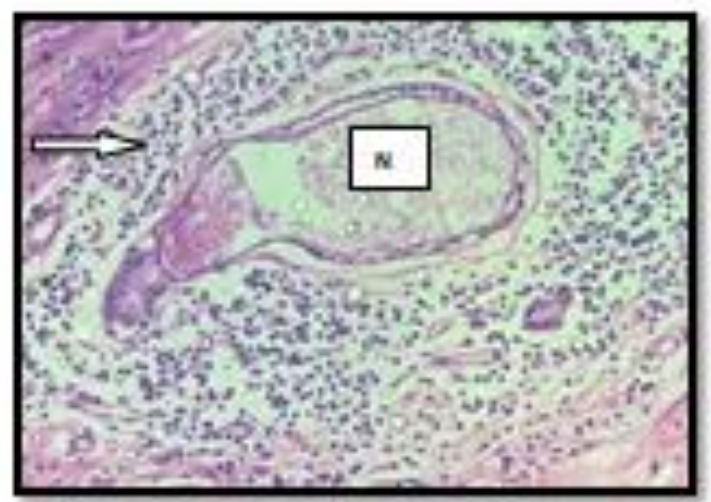

Fig No. 6 : Photomicrograph of Paraffin Section slide, Duct ectasjia(H \& E; 40x) shows dilated duct filled with necrotic material $(\mathrm{N})$ and surrounded by dense fibrocollagenous tissue and lymphocytic infiltrate(white arrow).

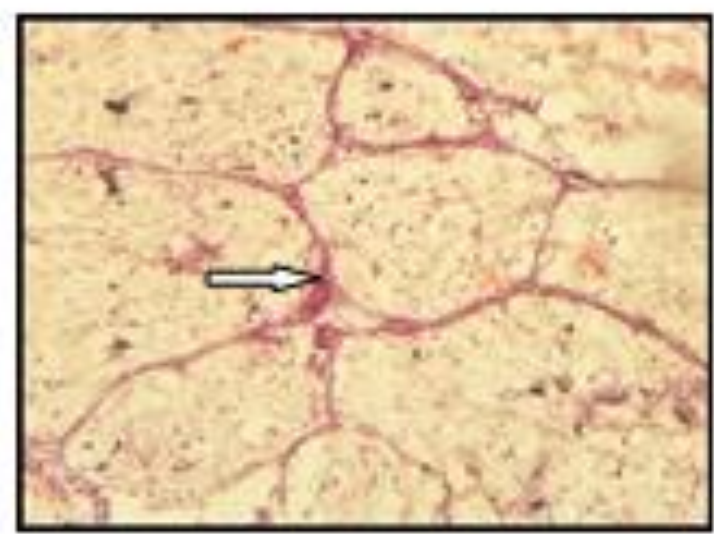

Fig. 8: Photomicrograph of Frozen section slide, phylloides tumor $(\mathrm{H}$ $8 \mathrm{E}_{-10 \mathrm{x}}$ )show tumor comprised of exaggerated intracanalicular growth pattern with leaf- like projection(white arrow) into cilated ducts. Stroma is abundant fibrocollagenous. 


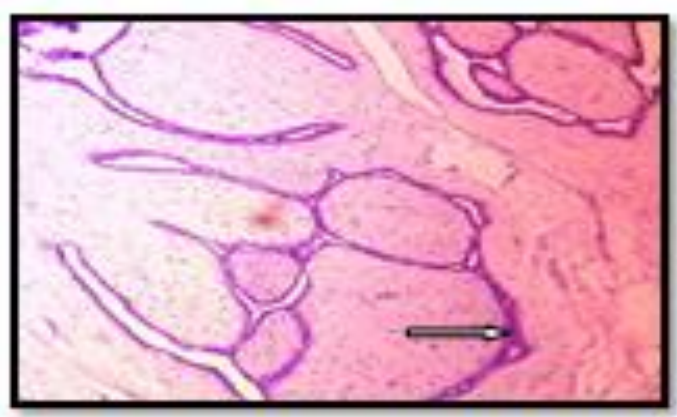

Fig. 9: Photomicrograph of paraffin section slide, phylloides tumor $(\mathrm{H}$ \&E - 10x s how tumor comprised of exaggerated growth pattern with leaf- like projection (white arrow) into dilated ducts. Stroma is abundant, fibrocollagenous.

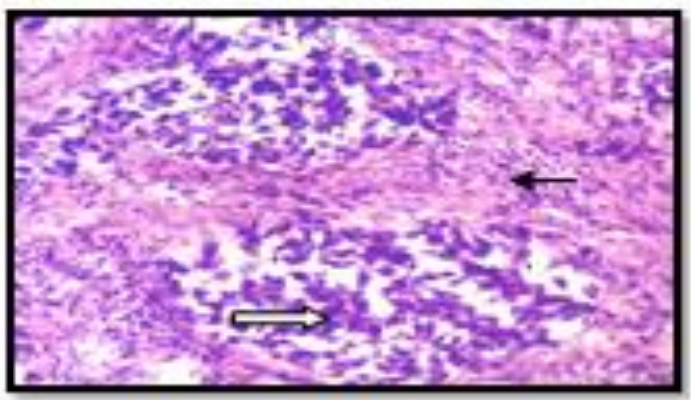

Fig. 11 : Photomicrograph of Frozen section slide, IDC (H \& E ; 40 X) shows tumour tissuefwhite arrow) comprised of groups, strands and gland-like structures formed by large, round to oval cells having large, hyperchromatic pleomorphic nuclei and scanty cytoplasm. Stroma is dense fibrocollagenous, (black arrow).

\section{Discussion}

Breast carcinoma is one of the commonest cancer among females in India preceded only by cervical cancer. $^{(10,11)}$ Early screening and diagnosis of breast lesions can aid in prevention as well as accurate management of the patients thus alleviating discomfort and anxiety in the process. $^{(12,13)}$ The present study confirms the clinical utility and efficacy of FNAC, Frozen Section and Histopathological study in the

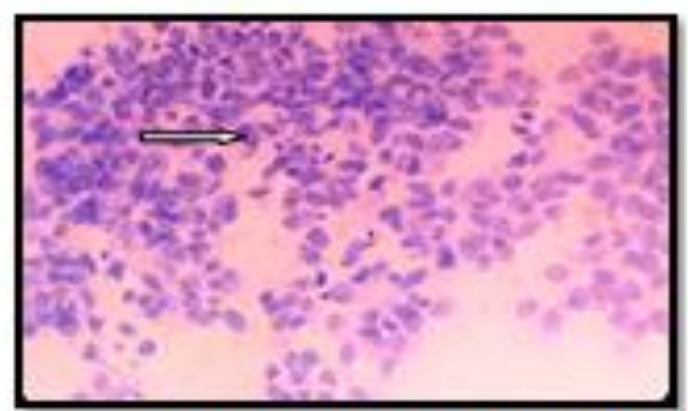

Fig. 10 : Photomicrograph of FNAC slide, IDC (H \&E ; $40 \mathrm{X})$ shows large ductal epithelial cells(white arrow) showing hyperchromatic, pleomorphic nuclei and scanty cytoplasm on baemorrbagic background

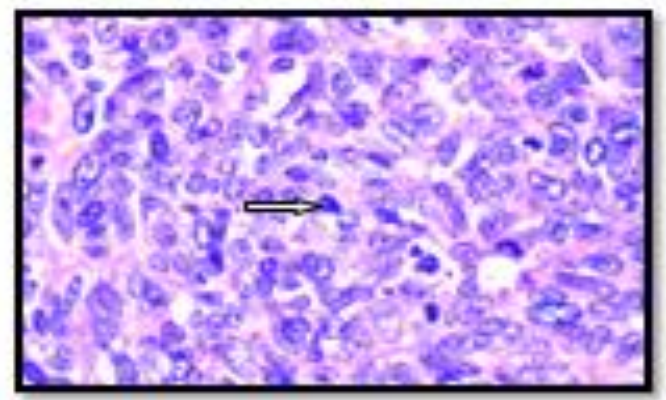

Fig. 12 : Photomicrograph of Paraffin section slide, IDC-High grade (H \& E ; $40 \mathrm{X}$ ) shows tumour tis sue comprised of large, round to oval tumor cells having large, pleomorphic, hyperchromatic (white arrow) and at places vesicular nuclei with prominent nucleoli and scanty cytoplasm along with stroma between tumor cells.

evaluation of the patient with breast lesions and subclassify them as benign and malignant breast disease wherever possible.

In the present study, most of the patients were in the age group of 31-40 years followed by 51-60 years which was comparable with the study done by Shrestha et $\mathrm{al}^{(14)}$.

Most common side of involvement of breast lesion is left side, this finding correlates with the study done by Reddy ${ }^{(15)}$ (1958) which showed 
left side as the most common side of involvement in breast lesions. In our study we found one $(1.96 \%)$ case of bilateral side breast involvement. Most of the patients presented with palpable breatlumps (48 cases), 1 case of nipple discharge and 2 cases of palpable axillary lymph nodes.

In our study, most of the patients 35 cases $(68.62 \%)$ presented with breast lesions within 0 to 6 months.

In the present study, on FNAC, the benign or nonmalignant breast lesions were found in the $43.13 \%$ cases and malignant breast lesion in $56.86 \%$ cases, this result was similar to the study done by Sheikh et al. ${ }^{(16)}$

Rakhshindah Bajwa et al., found that among benign breast lesions (232 cases), fibroadenoma was the commonest benign breast lesion, 161 cases $(69.39 \%)^{(17)}$.

In our study, FNAC showed 18 cases (35.29\%) of fibroadenoma being the commonest benign lesion followed by 3 cases $(5.88 \%)$ of phylloides tumor and 1 case $(1.96 \%)$ of duct ectasia. Out of the 29 cases $(56.86 \%)$ of malignant breast lesions, all the cases are of infiltrating duct carcinoma as the most common malignant breast lesion.

On Frozen section study, 16 cases $(31.37 \%)$ of fibroadenoma being the commonest benign lesion followed by 3 cases $(5.88 \%)$ of phylloides tumor and 1 case $(1.96 \%)$ of duct ectasia. Out of the 31 cases $(60.78 \%)$ of malignant breast lesions, all the cases are of infiltrating duct carcinoma as the most common malignant breast lesion.

In the present study, surgically resected margins of all the malignant tumors are free of tumor tissue on frozen section and histopathological examination.

On HPE, 14 cases $(27.45 \%)$ of fibroadenoma being the commonest benign lesion followed by 3 cases $(5.88 \%)$ of phylloides tumor and 1 case $(1.96 \%)$ of duct ectasia. Out of the 33 cases $(64.70 \%)$ of malignant breast lesions, all the cases are of infiltrating duct carcinoma as the most common malignant breast lesion.

Table 7 Showing comparison of statistical analysis of results of sensitivity, specificity \& accuracy of FNAC diagnosis of breast disease between different studies (Literature Review)

\begin{tabular}{|c|c|c|c|c|}
\hline ar & Author & $\begin{array}{c}\text { Sensitivity } \\
(\%)\end{array}$ & $\begin{array}{c}\text { Specificity } \\
(\%)\end{array}$ & $\begin{array}{c}\text { Accuracy } \\
(\%)\end{array}$ \\
\hline 1 & $\begin{array}{l}\text { Rocha and } \\
\text { Nadkarni }^{(18)}(1997)\end{array}$ & 93.8 & 98.21 & --- \\
\hline 2 & 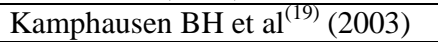 & 90 & 100 & --- \\
\hline 3 & Naggada $^{(20)}(2007)$ & 95.7 & 98.7 & 97.7 \\
\hline 4 & 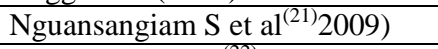 & 92.5 & 90.2 & 91.2 \\
\hline 5 & Ahmed H.G.et $\mathrm{al}^{(22)}(2009)$ & 92.6 & 95.2 & --- \\
\hline 6 & Pudasaini S et.al ${ }^{(23)}(2011)$ & 93.3 & 100 & --- \\
\hline 7 & 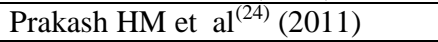 & 94.5 & 98 & 97 \\
\hline 8 & SushmaYalavarthiet al ${ }^{(25)}(2014)$ & 100 & 88.5 & --- \\
\hline 9 & $\begin{array}{l}\text { Paramesh\&Saha } \\
\text { et } \mathrm{al}^{(26)}(2015)\end{array}$ & 95.45 & 100 & 98.18 \\
\hline 10 & Daramola A Oet $\mathrm{al}^{(27)}(2015)$ & 95.4 & 88.9 & --- \\
\hline 11 & $\overline{\text { Waghmare et al }^{(28)}(2016)}$ & 88.24 & 100 & --- \\
\hline 12 & David E Ibikunle et.al ${ }^{(29)}(2017)$ & 99.4 & 100 & --- \\
\hline 13 & Sanjay C Chauhan et.al ${ }^{(30)}(2017)$ & 98.24 & 98.93 & --- \\
\hline 14 & Farida Begum et $\mathrm{al}^{(31)}$ & -- & -- & 98.1 \\
\hline 15 & DrVasundharaGardas $^{(32)}(2018)$ & 66.66 & 100 & --- \\
\hline 16 & Present study & 94.44 & 84.85 & 88.24 \\
\hline
\end{tabular}

(---):- parameter not calculated in the study.

Our study shows $94.44 \%$ Sensitivity, $84.85 \%$ specificity and accuracy of $88.24 \%$ which is comparable with results obtained in other studies in the literature. 
Table 8 Comparison of sensitivity, specificity, positive predictive value, negative predictive value and accuracy of Frozen Section in diagnosis of breast disease between different studies (Literature Review)

\begin{tabular}{|c|c|c|c|c|c|c|}
\hline $\begin{array}{l}\text { Sr } \\
\text { No }\end{array}$ & Author & $\begin{array}{l}\text { Sensitivity } \\
(\%)\end{array}$ & $\begin{array}{l}\text { Specificity } \\
(\%)\end{array}$ & $\begin{array}{l}\text { PPV } \\
(\%)\end{array}$ & $\begin{array}{l}\text { NPV } \\
(\%)\end{array}$ & $\begin{array}{c}\text { Accuracy } \\
(\%)\end{array}$ \\
\hline 1 & $\begin{array}{l}\text { Hanzal E et al }^{(33)} \\
(1992)\end{array}$ & 97.45 & 100 & --- & --- & --- \\
\hline 2 & $\begin{array}{l}\text { Hou MF et al }{ }^{(34)} \\
\text { (1995) }\end{array}$ & 99.1 & 100 & --- & --- & --- \\
\hline 3 & $\begin{array}{l}\text { Simonetta et a }{ }^{(8)} \\
(1995)\end{array}$ & 91.7 & 99.2 & --- & --- & --- \\
\hline 4 & $\begin{array}{l}\text { H Haeri et al } \\
(2002)\end{array}$ & 95.4 & 92.4 & --- & --- & 100 \\
\hline 5 & $\begin{array}{l}\text { PV Karve et al }{ }^{(36)} \\
(2005)\end{array}$ & 99.36 & 100 & 100 & 98.77 & 99.82 \\
\hline 6 & $\begin{array}{c}\text { Nuzhat S et al }{ }^{(37)} \\
(2005)\end{array}$ & 99.3 & 93 & 96.6 & 99.3 & 99 \\
\hline 7 & $\begin{array}{l}\text { Tarek MN, et } \\
\mathrm{al}^{(38)}(2008)\end{array}$ & 100 & 100 & --- & --- & 100 \\
\hline 8 & $\begin{array}{l}\text { Andreas H. Brunner } \\
\text { et } \mathrm{al}^{(39)}(2009)\end{array}$ & 95 & 100 & 100 & 90 & --- \\
\hline 9 & $\begin{array}{l}\text { F.Caruso et } \\
\mathrm{al}^{(40)}(2011)\end{array}$ & 83 & 93 & 62 & 97 & 94 \\
\hline 10 & $\begin{array}{l}\text { Shah Alam Sheikh et } \\
\mathrm{al}^{(16)}(2016)\end{array}$ & 97.37 & 100 & 100 & --- & 98.57 \\
\hline 11 & Present Study & 88.89 & 87.88 & 80.00 & 93.55 & 88.24 \\
\hline
\end{tabular}

PPV: Positive Predictive Value; NPV:- Negative Predictive Value (---):- parameter not calculated in the study.

In present study, sensitivity, specificity, positive predictive value, negative predictive value and accuracy of Frozen section is $88.89 \%, 87.88 \%$, $80.00 \%, 93.55 \%$ and $88.24 \%$ respectively which is low as compared to those in other studies may be because of low sample size.

\section{Conclusion}

To conclude, F.N.A.C. is a simple, rapid, cost effective, non-invasive procedure in the early diagnosis of breast lesions and not associated with any complications of the procedure. Despite increasing popularity and undisputed utility of FNAC, there are cases where frozen section still stands out as the method of choice for rapid diagnosis mainly for determining the resection margins of the lesion and the extent of metastasis in case of malignant lesion to ensure no residual tumour mass thus helping in further treatment and follow-up of patients. Final histopathological study is required to accurately arrive at a definitive diagnosis along with IHC marker study which is considered as a gold standard for patient care.

Thus, a judicious selection of one or more of these modalities is essential in every patient presenting with a suspicious breast lump.

\section{References}

1. Venugopal K, Balakrishna P, Nikshita N. FNAC Accuracy in Diagnosis of Breast lesions. Journal of Evolution of Medical and Dental Sciences. 2014;3(12):3062-9.

2. Dennison G, Anand R, Makar SH. A prospective study of use of FNAC and core biopsy in the diagnosis of breast 
cancer. Breast Journal, 9(6), 2003, 491493

3. Pradhan M, Dhakal H. Study of breast lump of 2246 cases by fine needle aspiration. J Nepal Med Assoc, 47, 2008, 2059.

4. Ariga R, Bloom K, Reddy VB, Kluskens L, Francescatti D, Dowlat K, et al. Fineneedle aspiration of clinically suspicious palpable breast masses with histopathologic correlation. Am J Surg, 184, 2002, 410-3.

5. Klein S. Evaluation of palpable breast masses. AmFam Physician, 71(9), 2005, 1731-8.

6. Shabot M, Goldberg I, Schick P, Nieberge R, Pilch YH. Aspiration cytology is superior to Tru-cut needle biopsy in establishing the diagnosis of clinically suspicious breast masses. Ann Surg, 196, 1992, 122.

7. Sayami P, Singh BM, Singh Y, Timila R, Shrestha U, Sayami G. Retrospective analysis of breast cancer cases and surgical treatment in a period of ten years. J Nepal Med Assoc, 40, 2001, 112-9.

8. Bianchi S, Palli D, Ciatto S, Galli M, Giorgi D, et al. Accuracy and reliability of frozen section diagnosis in a series of 627 non palpable breast lesion. Am J Clinical Pathology, 103, 1995, 199-205.

9. http://ec.europa.eu/health/ ph_projects/2002/cancer/ fp_cancer_2002_ext_guid_01.p

10. Pandey JS, Sayami G, Dali S, Shrestha HG, Shrestha B, Adhikari RC, et al. Fine needle aspiration cytology of breast lump in TU Teaching Hospital. Nep. Med Assoc. 2002;41:388-91.

11. Manohar P, Adhikari RC, Sigdel B, Basnet RB, Amatya VJ. Present cancer status in TU teaching hospital. JSSN. 1992;2:16-23.

12. Hughes JE, Royle GT, Buchanan R, Taylor I. Depression and social stress among patients with benign breast disease.
British Journal of Surgery. 1986;73 (12): 997-9.

13. 13.Ellman R, Angeli N, Christians A, Moss S, Chamberlain J, Maguire $P$. Psychiatric morbidity associated with screening for breast cancer. British Journal of Cancer. 1989;60(5):781.

14. Shrestha HG, Dali S, Sayami G, Osti B, Amatya VJ, Basnet RB. Present cancer scenario and its changing pattern at TU Teaching Hospital, Nepal. J Nep Med Assoc. 1997;35:45-51.

15. 15.Reddy DG, Reddy CR. Carcinoma of the breast, its incidence and histological variants among South Indians. Indian journal of medical sciences. 1958;12(4): 228.

16. Shah Alam Sheikh. et al. Journal of Science.2016; 6(3);191-201.

17. Bajwa R, Zulfiqar T. Association of fine needle aspiration cytology with tumor size in palpable breast lesions. Biomedica. 2010;26:124-9.

18. Rocha PD, Nadkarni NS, Menezes S. Fine needle aspiration biopsy of breast lesions and histopathologic correlation. An analysis of 837 cases in four years. Actacytologica. 1997;41(3):705-12.

19. Kamphausen BH, Toellner T, Ruschenburg I. The value of ultrasoundguided fine-needle aspiration cytology of the breast: 354 cases with cytohistological correlation. Anticancer research. 2003; 23(3C):3009-13.

20. Nggada HA, Tahir MB, Musa AB, Gali BM, Mayun AA, Pindiga UH, et al. Correlation between histopathologic and fine needle aspiration cytology diagnosis of palpable breast lesions: a five-year review. African journal of medicine and medical sciences. 2007;36(4):295-8.

21. Nguansangiam S, Jesdapatarakul S, Tangjitgamol S. Accuracy of Fine Needle Aspiration Cytology from Breast. Asian Pacific Journal of Cancer Prevention. 
2009;10:1-4.

22. Ahmed HG, Ali AS, Almobarak AO. Utility of fine needle aspiration as a diagnostic technique in breast lumps. Diagnostic cytopathology. 2009;37(12): 881-4.

23. Pudasaini S, Talwar OP. Study of fine needle aspiration cytology of breast lumps and its histopathological correlation in Pokhara Valley. Nepal Medical College journal: NMCJ. 2011;13(3):208-12.

24. Muddegowda PH, Lingegowda JB, Kurpad R, Konapur PG, Shivarudrappa AS, Subramaniam PM. The value of systematic pattern analysis in FNAC of breast lesions: 225 cases with cytohistological correlation. Journal of Cytology/Indian Academy of Cytologists. 2011;28(1):13.

25. Yalavarthi S, Tanikella R, Prabhala S, Tallam US. Histopathological and cytological correlation of tumors of breast.Medical Journal of Dr. DY Patil University. 2014;7(3):326.

26. Paramesh AS, Kariappa TM. Correlation of fine needle aspiration cytology and histopathology in palpable breast lesions in 100 patients of KVG Medical College \& Hospital, Sullia, Karnataka. International Journal of Applied Research. 2015;1(8): 422-7.

27. Daramola AO, Odubanjo MO, Obiajulu FJ, Ikeri NZ, Banjo AA. Correlation between fine-needle aspiration cytology and histology for palpable breast masses in a Nigerian tertiary health institution. International journal of breast cancer. 2015;1-5.

28. Waghmare RS, Sakore DS, Rathod SB. Fine needle aspiration cytology of breast lesions and correlation with histopathology. Int J Res Med Sci. 2016;4: 4416-21.

29. Ibikunle DE, Omotayo JA, Ariyibi OO. Fine needle aspiration cytology of breast lumps with histopathologic correlation in Owo, Ondo State, Nigeria: a five-year review. Ghana medical journal. 2017; 51(1):1-5.

30. Chauhan SC, Sarvaiya AN. Cytological and Histopathological Correlation of Breast Lump: A 3 Year Study at Tertiary Care Center. Annals of Pathology and Laboratory Medicine. 2017;4(3):A292296.

31. Farida Begum, P. Ravi Kumar. Diagnostic correlation of palpable breast masses by cytology and histopathology: A prospective study.IAIM.2018;5(11):44-49.

32. Gardas V. Cytological study of breast lumps with histopathological correlation. Indian J Basic Appl Med Res. 2018;7:18592

33. Hanzal E, Gitsch G, Joura E, Dadak C, Breitenecker G. The value of intraoperative rapid biopsy study in diagnosis of breast cancer. Geburtshilfe und Frauenheilkunde. 1992;52(3):161-4.

34. Hou MF, Huang TJ, Lin HJ, Sheen YY, Huang CJ, Huang YS, et al. Frozen section of diagnosis of breast lesions. Gaoxiongyixuekexuezazhi $=$ The Kaohsiung journal of medical sciences. 1995;11(11):621-5.

35. Haeri H, Djamali M, Ahmadinejad M. Comparison of the cytology technique and the frozen section results in intraoperative consultation of the breast lesions. Acta Medica Iranica. 2002:203-6.

36. Karve PV, Jambhekar NA, Desai SS, Chinoy RF. Role of frozen section evaluation in patients with breast lumps: A study of 251 cases. Indian J Surg 2005; 67:241-5.

37. Kayani N, Sultana N. Validity of frozen section in the diagnosis of breast lumps: 5 years experience at the Aga Khan University Hospital. Journal of Pakistan Medical Association. 2005;55(12):533.

38. El-Bolkainy TM, Shabaan HA, Abodeif WT, El-Bolkainy MN, El-Tony A. Intra- 
operative diagnosis of breast mass-lesions: comparison of the validity of touch smear preparation and frozen section techniques. Journal of the Egyptian National Cancer Institute. 2008;20(1):63-9.

39. Brunner AH, Sagmeister T, Kremer J, Riss $\mathrm{P}$, Brustmann $\mathrm{H}$. The accuracy of frozen section analysis in ultrasound-guided core needle biopsy of breast lesions.BMC cancer. 2009;9(1):341.

40. Caruso F, Ferrara M, Castiglione G, Cannata I, Marziani A, Polino C, et al. Therapeutic mammaplasties: full local control of breast cancer in one surgical stage with frozen section. European Journal of Surgical Oncology (EJSO). 2011;37(10):871-5. 